\title{
Responses of synovial fluid and peripheral blood mononuclear cells to bacterial antigens and autologous antigen presenting cells
}

\author{
Ina S Klasen, Marie José Melief, Tom J G Swaak, Anton J Severijnen, Maarten P Hazenberg
}

\begin{abstract}
The specificity of $\mathbf{T}$ cells in the inflamed joints of patients with rheumatoid arthritis (RA) has been the subject of much study. Bacterial antigens are suspect in the aetiology of rheumatic diseases. The responsiveness of the mononuclear cell fraction of peripheral blood and synovial fluid of patients with $\mathbf{R A}$ and of patients with rheumatic diseases other than RA to bacterial antigens such as cell wall fragments of the anaerobic intestinal flora, cell wall fragments of Streptococcus pyogenes, intestinal flora derived peptidoglycan polysaccharide complexes, the 65 kilodalton protein of Mycobacterium tuberculosis, and muramyldipeptide was investigated. No significant difference in response was found to all these bacterial antigens in the synovial fluid of patients with RA compared with the responses in patients with other rheumatic diseases. The highest responsiveness in the synovial fluid of the patients with RA was to the streptococcal cell wall fragments and to the 65 kilodalton protein.
\end{abstract}

Higher responses to several bacterial antigens in the synovial fluid of patients with RA were found compared with peripheral blood from the same patient group. The antigen presenting cell population of the synovial fluid in patients with $R A$ and the patients with other rheumatic diseases was found to be stimulatory for autologous peripheral blood $\mathbf{T}$ cells even in the absence of antigen. This suggests an important role for the synovial antigen presenting cell in the aetiology of inflammatory joint diseases.

(Ann Rheum Dis 1993; 52: 127-132)

Department of Immunology,

Erasmus University

Rotterdam and

Department of

Rheumatology,

Dr Daniel den Hoed

Clinic Rotterdam,

The Netherlands

I S Klasen

M J Melief

T J G Swaak

A J Severijnen

M P Hazenberg

Correspondence to:

Dr M P Hazenberg,

Department of

Immunology,

PO Box 1738

3000 DR Rotterdam,

The Netherlands.

Accepted for publication

2 September 1992
Many workers in the last decade have been interested in the specificity of the synovial $T$ cell in rheumatic disease. These studies are based on the idea that the triggering antigen of rheumatic disease can be found from the specificity of the $T$ lymphocytes at the site of the inflammation (reviewed by Keat and Knight for reactive arthritis ${ }^{1}$ ). In reactive arthritis the triggering antigens are thought to be antigens of the microbes that cause the infections of the gut such as chlamydia, yersinia, or salmonella. ${ }^{2}$ Antigens of these bacteria have indeed been detected in synovial cells, ${ }^{3-7}$ and $T$ cell specificity for these antigens has been found in the synovium. . $^{-10}$

In rheumatoid arthritis (RA) the specificity of mononuclear cells, preferentially in the synovial fluid, for antigens of Mycobacterium tuberculosis ${ }^{11}$ and especially for the 65 kilodalton heat shock protein ${ }^{12}$ has been reported. $T$ cell reactivity to these heat shock proteins has also been described in reactive arthritis. ${ }^{13}{ }^{14}$ There is now much interest in the cross reactivity of exogenous and endogenous heat shock proteins, which is thought to be pivotal in the aetiology of rheumatic disease. ${ }^{15} 16$ The presence in the synovial fluid of $\gamma \delta \mathrm{T}$ cell receptor positive cells specific for mycobacterial proteins has been reported. ${ }^{17}$ Res et al, however, have reported that the $T$ cell responses to the acetone precipitable fraction of $M$ tuberculosis found in the synovial fluid of patients with RA cannot be ascribed to the 65 kilodalton protein but to another microbial antigen also present in Escherichia coli. ${ }^{18}$ Moreover, peripheral blood $\gamma \delta$ cells were shown to be responsive to $M$ tuberculosis but not to the 65 kilodalton protein. ${ }^{19}$ This paper is therefore mainly focused on bacterial antigens other than heat shock proteins.

In animal models bacterial preparations have been used to induce arthritis. Mycobacterium tuberculosis in oil in the base of the tail of rats is well known as the adjuvant arthritis model, first described by Pearson and Wood. ${ }^{20}$ In the streptococcal model streptococcal cell walls in a watery solution are injected intraperitoneally into rats to induce chronic arthritis. ${ }^{21}$

Bacteria such as Mycobacterium and Streptococcus are probably not bacteria to which we are in continuous close contact. It can be suggested that the bacterial load in the intestine to which we are in lifelong close contact might be more important for the induction and chronicity of RA. The results of Severijnen and coworkers are therefore of interest. ${ }^{22-25}$ They have shown that cell wall fragments of the anaerobic intestinal flora can be arthritogenic in a rat model. Cell wall fragments consisting of peptidoglycan polysaccharide complexes of the anaerobic bacterium Eubacterium aerofaciens, present in numbers $>10^{9} / \mathrm{g}$ faeces were shown to induce a severe and chronic arthritis in rats. Moreover, peptidoglycan polysaccharide complexes can be isolated in a soluble form from faeces. ${ }^{26}$ When isolated from ileostomy fluid the peptidoglycan polysaccharide complexes were shown to be arthritogenic in rats. ${ }^{27}$ Humans invariably harbour high antibody titres of the IgM, IgG, and IgA subclasses against peptidoglycan polysaccharide complexes. ${ }^{28} \mathrm{This}$ indicates that humans are in continuous close contact with structures with severe arthritogenic capacity.

This paper describes a study of the proliferation of mononuclear cells of the synovial fluid and peripheral blood of patients with RA to intestinal and other bacterial antigens. 
The antigen presenting cells from the synovium of patients with reactive arthritis have been reported to be potent in their antigen presenting capacities compared with the antigen presenting cells from peripheral blood. ${ }^{29}$ As we were anxious to find out whether any existing responses were caused by the presence of an antigen specific $T$ cell population or by a specialised antigen presenting population we determined the proliferation of separated synovial fluid $T$ or peripheral blood $T$ cells in the presence of non- $T$ cell fractions from synovial fluid or peripheral blood.

\section{Patients and methods}

SUBJECTS

Twenty patients fulfilling the criteria for RA, 12 patients with rheumatic disorders other than RA (six osteoarthritis, three with arthrosis as a result of a mechanical cause, one with psoriatic arthritis, one with tuberculous arthritis, and one with gout; these patients were selected as they had large amounts of synovial fluid), 10 healthy subjects (laboratory staff), and two patients with juvenile rheumatoid arthritis were studied. Table 1 gives the data, diagnosis, and drug treatment of the patients. Synovial fluid and peripheral blood samples were taken for diagnostic reasons and samples, with approval of the patient, were used for this study.

ISOLATION OF SYNOVIAL FLUID AND PERIPHERAL BLOOD MONONUCLEAR CELLS

Synovial fluid and peripheral blood samples were decoagulated with $0 \cdot 129 \mathrm{M}$ sodium citrate. Synovial blood cells were washed once in wash medium (RPMI 1640 (Gibco, Paisley, UK) with $1 \%$ pooled human $\mathrm{AB}$ serum, $25 \mathrm{mM}$ HEPES, $1 \mathrm{mM}$ sodium pyruvate, $2 \mathrm{mM}$ glutamate, 100 $\mathrm{U} / \mathrm{ml}$ penicillin, and $100 \mu \mathrm{g} / \mathrm{ml}$ streptomycin). The human serum used was prescreened to have no mitogenic effect on peripheral blood mononuclear cells from healthy donors in an $\left[{ }^{3} \mathrm{H}\right]$ thymidine incorporation assay.

Peripheral blood and synovial fluid mononuclear cells were separated by Ficoll (FicollPaque, Pharmacia LKB, Uppsala, Sweden) gradient centrifugation. The separated mononuclear cells were washed twice before use in the assays. Live cells were counted by trypan blue dye exclusion.
PROLIFERATION ASSAYS AND ANTIGENS/MITOGENS A total of $10 \% / \mathrm{ml}$ live synovial fluid or peripheral blood mononuclear cells were seeded at $100 \mu \mathrm{l} /$ well in round bottomed microtitre plates (Costar, Cambridge, UK) in complete medium. This is the wash medium as described earlier but supplemented with $15 \%$ human $A B$ serum. The antigens were added at twice the final concentration in $100 \mu \mathrm{l}$ complete medium to triplicate cultures. Streptococcal cell wall and eubacterial cell wall preparations were prepared as described previously. ${ }^{21-25}$ Peptidoglycan polysaccharide complexes were isolated from normal faeces according to procedures described by Hazenberg et al. ${ }^{26}$ Concanavalin $\mathrm{A}$ and muramyldipeptide were purchased from Sigma (MO, USA). The 65 kilodalton protein was a gift from Dr J D A van Emden, RIVM, Bilthoven, The Netherlands. For the eubacterial cell wall, streptococcal cell wall, peptidoglycan polysaccharide complexes, and muramyldipeptide preparations a $30 \mu \mathrm{g} / \mathrm{ml}$ concentration was used; for the 65 kilodalton protein and concanavalin A preparations $10 \mu \mathrm{g} / \mathrm{ml}$ was used.

The cells were cultured for four or six days in a humidified Heraeus (Hanau, Germany) incubator at $37^{\circ} \mathrm{C}, 5 \% \mathrm{CO}_{2}$. For the last 17 hours of culture $7 \cdot 4 \mathrm{kBa}\left[{ }^{3} \mathrm{H}\right]$ thymidine was added (specific activity $7 \cdot 4 \times 10^{7} \mathrm{kBa}$; Amersham, UK). The cultures were harvested by an automatic cell harvester (Costar) and counted in a $\beta$ counter (Packard, Brussels, Belgium) or a $\beta$ plate (Pharmacia, LKB, Turku, Finland).

The results are expressed as stimulation indices (SI)

\footnotetext{
Mean $\left[{ }^{3} \mathrm{H}\right]$ thymidine incorporation of triplicate cultures with antigen or mitogen $(\mathrm{cpm})$

$\mathrm{SI}=$

Mean [ ${ }^{3} \mathrm{H}$ ]thymidine incorporation of triplicate cultures in medium $(\mathrm{cpm})$
}

\section{MIXING EXPERIMENTS}

T cells were isolated from the synovial fluid or peripheral blood mononuclear cells by rosetting with sheep red blood cells. Sheep red blood cells were treated with $140 \mathrm{mM}$ 2-aminoethylisothiouronium bromide (Sigma) before use. A total of $2 \times 10^{6}$ mononuclear cells $/ \mathrm{ml}$ were mixed with the same volume of $1 \%$ 2-aminoethylisothiouronium bromide-sheep red blood cells, spun down at $200 \mathrm{~g}$, and incubated for five minutes at $0^{\circ} \mathrm{C}$. After resuspension the cells were ficollated. The sheep red blood cells in the $\mathrm{T}$ cell pellet of the gradient were lysed by $\mathrm{NH}_{4} \mathrm{Cl}$ treatment

Table 1 Characteristics of subjects

\begin{tabular}{|c|c|c|c|c|}
\hline Group & $\begin{array}{l}\text { No of subjects } \\
\text { seropositivel } \\
\text { seronegative: }\end{array}$ & Women/men & $\begin{array}{l}\text { Mean (SEM); } \\
\text { median (range) } \\
\text { age (years) }\end{array}$ & $\begin{array}{l}\text { Drugst (No of } \\
\text { patients }\end{array}$ \\
\hline Rheumatoid arthritis (RA) $(n=20)$ & $10 / 10$ & $11 / 9$ & $61 \cdot 3(17 \cdot 3) ; 68(22-82)$ & $\begin{array}{l}\text { None (2); Rif (3); Chl (2); } \\
\text { Au (2); DAA (2); NSAID (3); } \\
\text { MTX (3); Au + NSAID; } \\
\text { MTX + NSAID; DAA + } \\
\text { NSAID (2); Au + pred + } \\
\text { NSAID } \\
\text { None (10); NSAID (2) }\end{array}$ \\
\hline $\mathrm{RA}(\mathrm{n}=12)$ & ND & $5 / 7$ & $59 \cdot 9(19 \cdot 6) ; 61(23-87)$ & None $(10)$ \\
\hline Healthy subjects $(n=10)$ & ND & $5 / 5$ & $29 \cdot 8(6 \cdot 8) ; 29 \cdot 0(20-43)$ & None; $\mathrm{Au}$ \\
\hline Juvenile chronic RA $(\mathbf{n}=2)$ & $0 / 2$ & $1 / 1$ & $23 \cdot 5 ; 23 \cdot 5(23-24)$ & \\
\hline
\end{tabular}




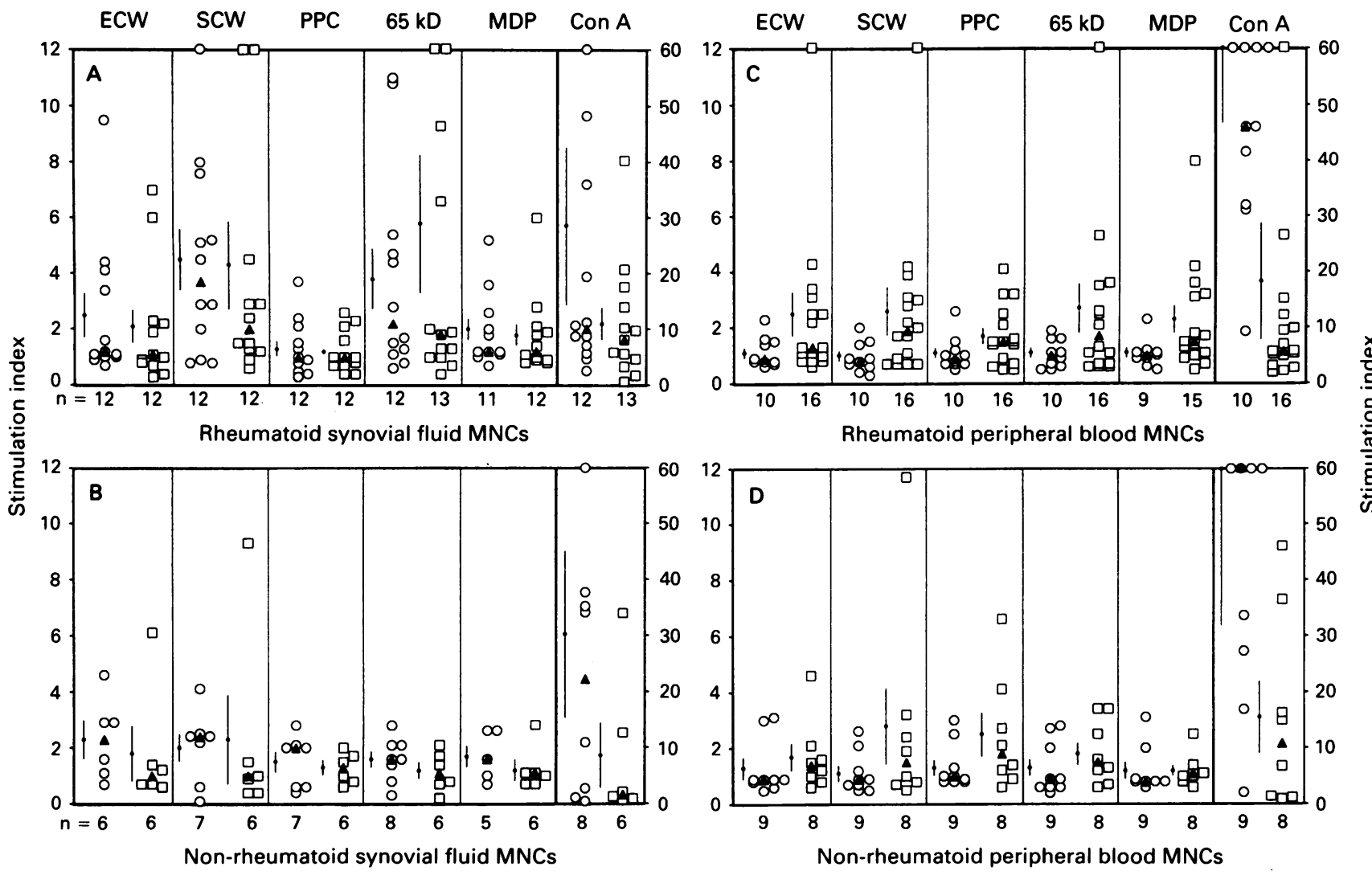

Figure 1 Stimulation indices (SI) of synovial fluid and peripheral blood $(P B)$ mononuclear cells $(M N C)$ so patients with $R A$ and patients with rheumatic diseases other than $R A$. (O) SI values determined at day 4 ; ( $\square)$ SI values determined at day $6 ;(\triangle)$ median value; $(-\bullet-)$ mean $(S E M)$ value. Values of $S I$ on the upper line represent values $\geqslant 12$ for the bacterial antigens or $S I \geqslant 60$ for concanavalin $A$. Mean or median values for concanavalin $A \geqslant 60$ are as follows: day 4 -mean (SEM) SI of concanavalin A from the RA group 60.3 (13.4); mean (SEM) SI of concanavalin A from the non-rheumatoid group $70 \cdot 7(28 \cdot 1)$, median $65 \cdot 1)$. Numbers $(n)$ of subjects tested are given; the first number is the number on day 4 , the second number on day 6. ECW $=$

eubacterial cell wall; $S C W=$ streptococcal cell wall; $P P C=$ peptidoglycan polysaccharide complexes; $65 \mathrm{kD}=65 \mathrm{kilodalton}$ protein; $M D P=$ muramyldipeptide Con $A=$ concanavalin $A$.

(155 $\mathrm{mM} \mathrm{NH} \mathrm{NCl}_{4}$ with $10 \mathrm{mM} \mathrm{KHCO}_{3}$, and $10 \mathrm{mM}$ EDTA) for three minutes at $4^{\circ} \mathrm{C}$. The cells in the interphase of the gradient were used as an antigen presenting cell source after 30 Gy gamma irradiation.

T cells were more than $95 \%$ pure after 2 aminoethylisothiouronium bromide-sheep red blood cells rosetting, as determined by FacScan analysis using monoclonal antibodies. In the proliferation assays $10^{5} \mathrm{~T}$ cells per well were used and $10^{5}$ antigen presenting cells irradiated with 30 Gy gamma radiation were added.

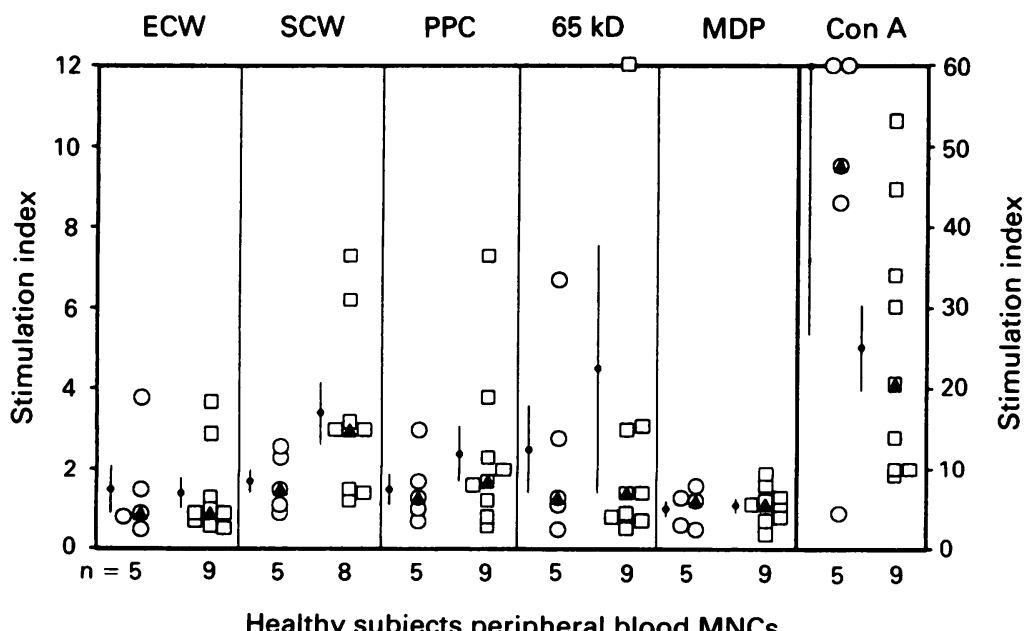

Figure 2 Stimulation indices (SI) of peripheral blood mononuclear cells (MNCs) from the group of healthy subjects. Numbers (n) of the subjects tested are given. Day 4: Mean (SEM) $S I$ of concanavalin $A$ 82.0 (33.2) ECW = eubacterial cell wall; $S C W=$ streptococcal cell wall; $P P C=$ peptidoglycan polysaccharide complexes; $65 k D=65$ kilodalton protein; $M D P=$ muramyldipeptide; Con $A=$ concanavalin $A$.
STATISTICS

The significance of the results was determined by the Mann-Whitney $U$ test. $p$ Values smaller or equal to 0.05 were considered significant.

Results

STIMULATION INDICES OF SYNOVIAL FLUID AND PERIPHERAL BLOOD MONONUCLEAR CELLS OF PATIENTS WITH RHEUMATOID ARTHRITIS, NON-RHEUMATOID PATIENTS, AND HEALTHY SUBJECTS

This paper reports the responses of mononuclear cell fractions of patients with rheumatic diseases to several bacterial antigens. Figure 1A shows the stimulation indices of mononuclear cells isolated from synovial fluid of patients with RA; fig $1 B$ gives the stimulation indices of synovial fluid mononuclear cells of patients with other inflammatory joint diseases on five bacterial antigens and the mitogen concanavalin $\mathrm{A}$.

When the stimulation indices of these two groups were compared by the Mann-Whitney U test, no significance was reached for all bacterial antigens. The highest responsiveness in the synovial fluid of patients with RA was found for the streptococcal cell wall fragments, but $p$ values were not significant (day $4, p=0.09$; day $6, p=0 \cdot 10)$. Responses of the 65 kilodalton protein, which in fig 1 appear higher in the synovial fluid of the group with RA compared with the group with other rheumatoid diseases also did not reach significance (day $4, p=0 \cdot 28$; day $6, p=0 \cdot 20$ ). The stimulation indices of the corresponding peripheral blood samples of 
patients with RA (fig 1C) and those with other rheumatic diseases (fig 1D) were also compared. No significance was reached for all antigens. Figure 2 shows the stimulation indices of the peripheral blood of healthy subjects. Some responsiveness to the bacterial antigens was found in these samples. A significantly higher response to mitogen concanavalin $\mathrm{A}$ was found on day $4(p=0.01)$ compared with peripheral blood from patients with RA.

As we were also interested in the differences in the responses between synovial fluid and peripheral blood in each group of patients, statistical analysis comparing these results was performed. $p$ Values for this analysis of the RA group are given in table 2 for the various antigens on two separate testing days. On day 4 significantly higher stimulation indices were found in synovial fluid compared with peripheral blood for the antigens streptococcal cell wall, 65 kilodalton protein, and muramyldipeptide. For the mitogen concanavalin A a significantly lower response was found in the synovial fluid. Comparison of the stimulation indices of synovial fluid and peripheral blood in the group with rheumatic diseases other than RA did not give significant differences.

\section{REPRODUCIBILITY OF THE ASSAYS}

One patient with RA was tested twice within one week. The results of the puncturing dates were comparable in the synovial fluid (high stimulation indices on streptococcal cell wall and 65 kilodalton protein) but not comparable in the peripheral blood. On the first puncturing date responses were found against all bacterial

Table 2 V Values of Mann-Whitney $U$ test comparing synovial fluid and peripheral blood of patients with $R A$

\begin{tabular}{lll}
\hline & Day 4 & Day 6 \\
\hline Eubacterial cell wall & 0.20 & 0.50 \\
Streptococcal cell wall & $0.003^{*}$ & 0.59 \\
Peptidoglycan polysaccharide & & \\
$\quad$ complexes & 0.74 & 0.29 \\
65 kilodalton protein & $0.02^{*}$ & 0.63 \\
Muramyldipeptide & $0.03^{*}$ & 0.53 \\
Concanavalin A & $0.01^{*}$ & 0.74 \\
\hline
\end{tabular}

"Significant $\mathrm{p}$ values.

For streptococcal cell wall, 65 kilodalton protein and muramyl dipeptide the stimulation indices of rheumatoid arthritis synovia fluid on day 4 are significantly higher, for concanavalin A signi-
fipentide fluid on day 4
ficantly lower. antigens; one week later these responses were no longer present. Interestingly, this patient developed pleuritis in the week between the two punctures. Figure 1 only shows the stimulation indices of the first puncture date.

In three patients synovial fluid was obtained from the left and right knee joints. These samples were tested separately. In all patients the resulting stimulation indices were comparable and the mean value of the right and the left knee joints is given in fig 1 .

ROLE OF THE ANTIGEN PRESENTING CELL SOURCE Together with the experiments described here, we wanted to determine whether any responses found in the synovial fluid are the result of an antigen specific $T$ cell population, or are found because of a specialised antigen presenting cell fraction. To investigate this mixing experiments were performed in which synovial fluid $T$ cell fractions were mixed with peripheral blood non$\mathrm{T}$ cells and peripheral blood $\mathrm{T}$ cells were mixed with synovial fluid non-T cells. Table 3 shows the stimulation indices of these experiments. It is shown that synovial fluid non-T cells were able to stimulate peripheral blood $\mathrm{T}$ cells, irrespective of the presence of antigen. This was not limited to the RA group but was also found in a patient with osteoarthritis, and, to some extent, in one of the two patients with juvenile RA.

\section{Discussion}

The first aim of our study was to investigate whether there is an antigen specific response to intestinal and other bacterial antigens in the mononuclear cell fractions of synovial fluid or peripheral blood from a group of patients with RA compared with a group of patients with rheumatic diseases other than RA. This last group consists of patients with other inflammatory joint diseases, mainly osteoarthritis. In comparing these two groups no significant differences were found for the bacterial antigens. The highest responsiveness in the synovial fluid of patients with RA compared with synovial fluid of the other group was found to the streptococcal cell wall fragments. No correlation was found between the response on

Table 3 Stimulation indices of mixing experiments of $T$ cell and non- $T$ cell fractions of synovial fluid and peripheral blood. Stimulation indices of peripheral blood and synovial fluid were determined without separation of the $T$ and non-T cell fraction. In the mixing experiments synovial fluid $T$ cells were isolated by 2-aminoethylisothiouronium bromide sheep red blood cells rosetting and $10^{5} T$ cells were mixed with $10^{5}$ non-T cells from the corresponding peripheral blood (peripheral blood antigen presenting cells) or $10^{5}$ peripheral blood T cells were mixed with $10^{5}$ synovial fluid antigen presenting cells per well. Patients No $4 a$ and $4 b$ are two separate experiments of two separate puncture dates for one patient

\begin{tabular}{|c|c|c|c|c|c|c|c|c|c|c|c|c|}
\hline \multirow[t]{2}{*}{$\begin{array}{l}\text { Patient } \\
\text { No }\end{array}$} & \multirow[t]{2}{*}{ Disease } & \multirow[t]{2}{*}{ Day } & \multicolumn{2}{|c|}{ Peripheral blood } & \multicolumn{2}{|l|}{ Synovial fluid } & \multicolumn{3}{|c|}{$\begin{array}{l}\text { Synovial fluid } T+\text { peripheral blood } \\
\text { antigen presenting cells }\end{array}$} & \multicolumn{3}{|c|}{$\begin{array}{l}\text { Peripheral blood } T+\text { synovial fluid } \\
\text { antigen presenting cells }\end{array}$} \\
\hline & & & $\begin{array}{l}\text { Streptococcal } \\
\text { cell wall }\end{array}$ & $\begin{array}{l}\text { Concan- } \\
\text { avalin } A\end{array}$ & $\begin{array}{l}\text { Streptococial } \\
\text { cell wall }\end{array}$ & $\begin{array}{l}\text { Concan- } \\
\text { avalin } A\end{array}$ & $\begin{array}{l}\text { Streptococial } \\
\text { cell wall }\end{array}$ & $\begin{array}{l}\text { Concan- } \\
\text { aralin A }\end{array}$ & $\begin{array}{l}\text { Antigen } \\
\text { presenting } \\
\text { cells }\end{array}$ & $\begin{array}{l}\text { Streptococcal } \\
\text { cell wall }\end{array}$ & $\begin{array}{l}\text { Concan- } \\
\text { az'alin A }\end{array}$ & $\begin{array}{l}\text { Antigen } \\
\text { presenting } \\
\text { cells }\end{array}$ \\
\hline 1 & RA & 4 & $0 \cdot 3$ & $99 \cdot 0$ & $8 \cdot 0$ & $179 \cdot 7$ & $1 \cdot 1$ & $119 \cdot 5$ & $1 \cdot 5$ & $18 \cdot 2$ & $323 \cdot 3$ & $10 \cdot 0$ \\
\hline 2 & RA & 4 & 0.8 & $73 \cdot 5$ & $2 \cdot 9$ & $48 \cdot 3$ & 0.1 & 8.9 & $0 \cdot 1$ & 0.6 & $12 \cdot 1$ & 0.1 \\
\hline 3 & RA & 4 & $2 \cdot 0$ & $157 \cdot 9$ & $7 \cdot 6$ & $36 \cdot 1$ & $0 \cdot 4$ & $35 \cdot 5$ & 0.4 & $7 \cdot 3$ & $130 \cdot 2$ & $5 \cdot 5$ \\
\hline ta & RA & 4 & 0.9 & $46 \cdot 1$ & $12 \cdot 9$ & $2 \cdot 6$ & NI) & 1.9 & 0.7 & 48 & 525.8 & $12 \cdot 5$ \\
\hline $4 b$ & RA & 6 & $1 \cdot 0$ & $17 \cdot 0$ & $3 \cdot 0$ & $27 \cdot 1$ & $1 \cdot 0$ & 4.8 & $2 \cdot 2$ & $178 \cdot 1$ & 177.0 & $357 \cdot 0$ \\
\hline 5 & JRA & 4 & 0.4 & $14 \cdot 8$ & 1.9 & $2 \cdot 8$ & $1 \cdot 8$ & $5 \cdot 8$ & 1.4 & $4 \cdot 3$ & 45.9 & $2 \cdot 1$ \\
\hline 6 & JRA & 4 & $1 \cdot 2$ & $164 \cdot 6$ & $4 \cdot 1$ & $99 \cdot 6$ & 0.5 & $39 \cdot 0$ & 0.5 & $2 \cdot 8$ & $685 \cdot 3$ & $3 \cdot 4$ \\
\hline 7 & ()A & 6 & $3 \cdot 2$ & $16 \cdot 3$ & $1 \cdot 5$ & $1 \cdot 3$ & $12 \cdot 7$ & 1.9 & 1.4 & NI) & NI) & ND \\
\hline 8 & ()A & + & $1 \cdot 8$ & $270 \cdot 0$ & 1.7 & $34 \cdot 1$ & $1 \cdot 8$ & $109 \cdot 5$ & $1 \cdot 0$ & $33 \cdot 2$ & $91 \cdot 3$ & $17 \cdot 2$ \\
\hline
\end{tabular}

NI) not determined; $R A=$ rheumatoid arthritis; JRA = juvenile rheumatoid arthritis; ()A osteoarthritis. 
streptococcal cell wall in the synovial fluid of patients with RA and positivity or negativity for rheumatoid factor production according to the Rose-Waaler test (data not shown).

The streptococcal cell wall and eubacterial cell wall are arthritogenic preparations in the rat model according to Cromartie et al. ${ }^{21}$ In our opinion the streptococci are not bacteria with which we are in continuous close contact as we are with the bacteria of the intestinal flora, which are our main interest. No significant responses were found to any of the bacterial antigens, however.

The bacterial antigens used here do not act as mitogenic stimulators as most of the suspensions of mononuclear cells from patients and healthy subjects did not show proliferative responses to these antigens.

There are several possibilities as to why we did not observe antigen specificity in the synovial fluid of patients with RA.

Firstly, antigen specificity only exists in an inflammation that is of short duration. Most of our patients with RA had long term disease. Holoshitz et al, in their work on the responsiveness of synovial fluid mononuclear cells to the acetone precipitable fraction of $M$ tuberculosis, have reported this to exist in short lasting disease. ${ }^{11}$ Secondly, transforming growth factor $\beta$ has been shown to be present in synovial fluid. ${ }^{30}$ This factor has suppressive activity on $\mathrm{T}$ cell proliferation and therefore might mask antigen specificity. This might also account for the low responsiveness of concanavalin $A$ in the synovial fluid, as has also been reported by others for several mitogens. ${ }^{31}{ }^{32}$ Finally, antigen specificity does not exist in synovial fluid. In some healthy subjects we also found a response to streptococcal cell wall and other bacterial antigens, so perhaps the responses to these bacterial antigens are a normal phenomenon. It could be assumed that a higher responsiveness in the synovial fluid is not the result of a specific $T$ cell population but of a specialised antigen presenting cell population. Another way to look at the results of fig 1 is to compare the responsiveness of peripheral blood and synovial fluid within one patient group. In the RA group a significantly higher responsiveness in the synovial fluid to several bacterial antigens compared with peripheral blood was found. In the RA group a significantly higher responsiveness in the synovial fluid compared with peripheral blood was found for the antigens streptococcal cell wall and muramyldipeptide and also for the 65 kilodalton protein, as has also been reported by others. ${ }^{11} 12$ Significance between peripheral blood and synovial fluid from patients with RA was only found in a four day proliferation assay; there was no significance in a six day assay. The critical kinetics of the proliferation assays might be the cause of this. It must also be taken into account that after a longer period of culturing, overgrowth of the cultures may occur, which results in a low $\left[{ }^{3} \mathrm{H}\right]$ thymidine incorporation and in an underestimation of the proliferation of the culture. For concanavalin A stimulation on day 6 this almost certainly plays a part. The influence of drugs is always difficult to estimate. In the comparison between the RA group and the group with rheumatic diseases other than RA this might have influenced the results. In the comparison between synovial fluid and peripheral blood within one patient group we assume that this influence is the same in the two cell sources. To investigate further the cause of the higher responsiveness of the synovial fluid compared with the peripheral blood, mixing experiments of $T$ cells and the antigen presenting cells of peripheral blood and synovial fluid were performed. Table 3 shows that the antigen presenting cells of synovial fluid have a stimulatory capacity of peripheral blood $\mathrm{T}$ cells even in the absence of antigen. Synovial fluid T cells were not stimulated by peripheral blood antigen presenting cells. This suggests that the antigen presenting cell population of the synovial fluid from patients with and without RA is itself strongly stimulatory. This could be the result of several properties of the synovial fluid antigen presenting cells, for example, a high class II expression, of different cytokine production or a specialised adhesion molecule profile. These properties might account for the higher responsiveness in synovial fluid as was found by us and several other workers. Our results are in agreement with the results published by Life et al ${ }^{29}$ who studied the autologous response to synovial fluid antigen presenting cells in reactive arthritis; we, however, used a higher number of antigen presenting cells per $T$ cell than in their experiments.

In summary, our results show that responsiveness to intestinal bacterial antigens is not found in the synovial fluid of patients with RA. The stimulatory capacities of synovial antigen presenting cells might be of greater importance.

The authors acknowledge Mrs H J Elsenbroek-de Jager for assistance in the preparation of the manuscript and $\mathrm{Mr} \mathrm{T} M$ van Os for preparation of the figures. The work was supported by the
Dutch League Against Rheumatism. Dr J D A van Emden (RIVM, Bilthoven, The Netherlands) kindly provided the 65 Rilodalton protein.
kiloven

1 Keat A C, Knight S C. Do synovial fluid cells indicate the cause of reactive arthritis? F Rheumatol 1990; 17: 1257-9.

2 Toivanen A, Toivanen P, eds. Reactive arthritis. Boca Raton: CRL Press, 1988.

3 Granfors K, Jalkanen S, Von Essen R, et al. Yersinia antigens in synovial-fluid cells from patients with reactive arthritis. $N$ Engl 7 Med 1989; 320: 216-21.

4 Hammer M, Zeidleer H, Klimsa S, Heesemann J. Yersinia enterocolitica in the synovial membrane of patients with Yersinia induced arthritis. Arthritis Rheum 1990; 33: 1795-1800.

5 Viitanen A M, Arstila T P, Lahesmaa R, Granfors K, Skurnik M, Toivanen $P$. Application of the polymerase chain reaction and immunofluorescence techniques to the detection of bacteria in Yersinia-triggered reactive arthritis. Arthritis Rheum 1991; 34: 89-96.

6 Schumacher H R Jr, Magge S, Cherian P V, et al. Light and electron microscopic studies on the synovial membrane in Reiter's syndrome: immunocytochemical identification in Reiter's syndrome: immunocytochemical identification of Rheum 1988; 31: 937-46.

7 Granfors K, Jalkanen S, Lindberg A A, et al. Salmonella lipopolysaccharide in synovial cells from patients with lipopolysaccharide in synovial cells from

8 Gaston J S H, Life P F, Granfors K, et al. Synovial T lymphocyte recognition of organisms that trigger reactive lymphocyte recognition of organisms that trigger reactive arthritis. Clin Exp Immunol 1989, 76: 348-53.

Hermann E, Fleischer B, Mayet W J, Poralla T, Meyer zum Büscherfelde $K \mathbf{H}$. Response of synovial $T$ cell clones to Yersinia enterocolitica in patients with Yersinia reactive arthritis. Clin Exp Immunol 1989; 75: 365-70.

10 Sieper J, Kingsley G, Palacios-Boix A, Pitzalis C, Treharne J, Hughes R, Keat A, Panayi G S. Synovial T lymphocyte specific immune response to Chlamydia trachomatis in Reiter's disease. Arthritis Rheum 1991; 34: 588-97. 
11 Holoshitz J, Klajman A, Drucker I, et al. T lymphocytes of rheumatoid arthritis patients show augmented reactivity to a fraction of mycobacteria cross-reactive with cartilage. Lance 1986; ii: 305-9.

12 Res P C M, Schaar C G, Breedveld F C, et al. Synovial fluid T cell reactivity against $65 \mathrm{kD}$ heat shock protein of mycobacteria in early chronic arthritis. Lancet 1988; ii: 478-80.

13 Gaston J S H, Life P F, Bailey L C, Bacon P A. In vitro responses to a 65 -kilodalton mycobacterial protein by synovial $\mathrm{T}$ cells from inflammatory arthritis patients. f Immunol 1989; 143: 2494-500.

14 Hermann E, Mayet W J, Lokse A W, Grevenstein J, Meyer zum Büschenfelde $\mathrm{K} \mathbf{H}$, Fleischer B. Proliferative response of synovial fluid and peripheral blood mononuclear cells to arthritogenic and non-arthritogenic microbial antigens and to the $65 \mathrm{kDa}$ mycobacterial heat shock protein. Med to the $65 \mathrm{kDa}$ mycobacterial heat sh

15 van Eden W. Heat shock proteins as immunogenic bacteria antigens with potential of regulating autoimmune arthritis. Immum Rev 1991; 121: 5-28.

16 Lamb J R, Bal V, Mendez-Samperio P, et al. Stress protein may provide a link between the immune response to infection and autoimmunity. International Immunology 1989; 1: 191-6.

17 Holoshitz J, Koning F, Coligan J E, de Bruyn J, Strober S Isolation of CD4-CD8-mycobacteria-reactive T lymphocyte clones from rheumatoid arthritis synovial fluid. Nature 1989; 339: 226-9.

18 Res P C M, Telgt D, van Laar J M, Oudkerk Pool M, Breedveld F C, de Vries R R P. High antigen reactivity in mononuclear cells from sites of chronic inflammation. Lancet 1990; 336: 1406-8.

19 Kabeliz D, Bender A, Schondelmaier S, Schoel H, Kaufman $S \mathbf{H}$. A large fraction of human peripheral blood $\gamma / \mathrm{d}^{+} T$ cells is activated by Mycobacterium tuberculosis but not by its $65 \mathrm{kD}$ heat shock protein. $\mathcal{F}$ Exp Med 1990; 171 $667-79$

20 Pearson C M, Wood F D. Studies of polyarthritis and othe lesions induced in rats by injection of mycobacteria adjuvant: I. General clinical and pathologic characteristics and some modifying factors. Arthritis Rheum 1959; 2 440-59.

21 Cromartie W J, Craddock J G, Schwab J H, Anderle S K, Yang $\mathrm{C} \mathrm{H}$. Arthritis in rats after systemic injection of streptococcal cells or cell walls. $\mathcal{F} \operatorname{Exp} M e d 1977 ; 146$ : $1585-602$.
22 Severijnen A J, Hazenberg M P, van de Merwe J P. Induction of chronic arthritis in rats by cell wall fragments of anaerobic coccoid rods isolated from the faecal flora of

23 Severiinen A J, van Kleef R, Hazenberg M P, van de Merwe $J$. Cell wall fragments of the major residents of the human intestinal flora induce chronic arthritis in rats. $\mathcal{F}$ Rheumato 1989; 16: 1061-8.

24 Severijnen A J, van Kleef R, Hazenberg M P, van de Merwe $J P$. Chronic arthritis induced in rats by cell wall fragments of Eubacterium species from the human intestinal flora. Infect Immun 1990; 58: 523-8.

25 Severijnen A J, Kool J, Swaak A J G, Hazenberg M P. Intestinal flora of patients with rheumatoid arthritis. Induction of chronic arthritis in rats by cell wall fragments from isolated Eubacterium aerofaciens strains. $\mathrm{Br}$ Rheumatol 1990; 29: 433-9.

26 Hazenberg M P, Pennock-Schröder A M, Wensinck F, van de Merwe J P. Effect of a soluble bacterial carbohydrate fraction on the viscosity of intestinal contents in health subjects and patients with Crohn's disease. Eur $\mathcal{F}$ Clin Invest 1989; 19: 61-4.

27 Kool J, Ruseler-van Embden J G A, van Lieshout L M C, $e$ al. Arthritis induction in rats by soluble peptidoglycanpolysaccharide complexes present in human intestinat contents. Arthritis Rheum 1991; 34: 1611-6.

28 Hazenberg M P, de Visser H, Bras M J J, Prins M E, van de Merwe J P. Serum antibodies to peptidoglycan-polysaccharide complexes from the anaerobic intestinal flora in patients with Crohn's disease. Digestion 1990; 47: 172-82.

29 Life P F, Viner N J, Bacon P A, Gaston J S H. Synovial fluid antigen presenting cells unmask peripheral blood responses to bacterial antigens in inflammatory arthritis. Clin Exp to bacterial antigens in inflam

30 Lotz M, Kekow J, Carson D A. Transforming growth factor$\beta$ and immune responses in synovial fluids. $\mathcal{f}$ Immuno 1990; 144: 4189-94.

31 Abrahamsen T G, Froland S S, Natvig J B. In vitro mitogen stimulation of synovial fluid lymphocytes from rheumatoid arthritis and juvenile rheumatoid arthritis patients: dissociation between the response to antigens and polyclonal mitogens. Scand F Immunol 1978; 7: 81-90.

32 Nilsson E, Von Stedingk L V, Biberfeld G. Immunoregulatory function of T8 and T4 cells from synovial fluid and blood of patients with rheumatoid antitis or or arthritis. Scand I Immunol 1986; 24: 729-37. 